\title{
EFFECT OF ACID STRESS ON GERMINATION AND EARLY SEEDLING GROWTH OF RED CLOVER
}

\section{Mandić ${ }^{1}$ Z. Tomić ${ }^{1}$, V. Krnjaja ${ }^{1}$, Z. Bijelić ${ }^{1}$, M. Žujović ${ }^{1}$, A. Simić ${ }^{2}$, S. Prodanović ${ }^{2}$}

\author{
${ }^{1}$ Institute for Animal Husbandry, Autoput 16, 11080, Belgrade-Zemun, Republic of Serbia \\ ${ }^{2}$ Faculty of Agriculture, Nemanjina 6, 11080, Belgrade-Zemun, Republic of Serbia \\ Corresponding author: violeta_randjelovic@yahoo.com \\ Original scientific paper
}

Abstract: The aim of this investigation was to estimate the effect of four $\mathrm{pH}$ levels of germination media (4, 5, 6 and 7) on seed germination energy (GE), germination $(\mathrm{G})$, percentage of dead or infected seeds (DIS), percentage of hard seed (HS), normal (NS) and abnormal seedlings (AS), root length (RL), shoot length (ShL), seedling length (SeL), fresh weight (FW) and dry weight (DW) of seedling, and seedling vigor index (SVI) in two red clover genotypes (cv. K-17 and $\mathrm{cv}$. Kolubara). The experiment was conducted in the laboratory conditions of the Institute for Animal Husbandry in Belgrade in January 2011.

The $\mathrm{pH}$ levels of germination media had significant effect on the NS $(\mathrm{P}<0.01)$, AS $(\mathrm{P}<0.01)$, RL $(\mathrm{P}<0.05)$, ShL $(\mathrm{P}<0.01)$, SeL $(\mathrm{P}<0.01)$, FW $(\mathrm{P}<0.01)$ and SVI $(\mathrm{P}<0.05)$. The lowest GE, G, NS, ShL, SeL, FW and SVI were found at $\mathrm{pH}$ 4. Also, the highest DIS, HS and AS were found at $\mathrm{pH} 4$. The genotype had significant effect on HS ( $\mathrm{P}<0.01)$, RL $(\mathrm{P}<0.01)$, ShL $(\mathrm{P}<0.01)$, SeL $(\mathrm{P}<0.01)$, FW $(\mathrm{P}<0.01)$ and SVI $(\mathrm{P}<0.01)$. Genotype and $\mathrm{pH}$ levels of germination media did not affect on GE, G, DIS and DW significantly.

Key words: genotype, germination, early seedling growth, $\mathrm{pH}$, red clover

\section{Introduction}

Red clover is planted on area of about 120.000 ha in Republic of Serbia, thanks to its adaptation to more acid and shallower soils, especially in mountainous regions. Tomić et al. (2007) stated that alfalfa is mainly grown in low land regions on soils of neutral to slight acid reaction, while red clover can be grown in hillymountainous regions on soils of poorer quality and slightly higher acidity. The $\mathrm{pH}$ of the surrounding media is one of the environmental factors that can severely limited legume production (Agić et al., 2009). Red clover tolerates acid soils (pH 5.2 - 6.0) better than alfalfa (Katić et al, 2006). Duke (1983) reported that red clover is better adapted than alfalfa at lower $\mathrm{pH}$ levels of $5.6-6.5$. The optimum 
$\mathrm{pH}$ range for red clover is $6.6-7.6$, but a range of $4.5-8.2$ is tolerated (Sattell et al., 1998). Taylor and Smith (1995) reported that the red clover grows well at a $\mathrm{pH}$ of 5.0 to 6.0 if all nutrient needs are satisfied, but a pH above 6.0 and adequate $\mathrm{Ca}$ are needed for maximum yields. It is sensitive to Mn toxicity, which is a concern when $\mathrm{pH}$ is below 5.7 in some soils. Many researchers, Tanaka et al. (1984), Yokota and Ojima (1995), Bukvic et al. (2007a; 2007b), reported that the $\mathrm{pH}$ might affect legume growth and development independently of other environmental factors. Significant correlations between field and laboratory measurements of germination have been examined in several leguminous crop species: alfalfa (Klos, 1999; Bukvic et al. 2007a), soybean (Szyrmer and Szczepanska, 1981), common bean (Dickson and Boettger, 1984; Saminy et al., 1987), and white clover (Bukvic et al., 2007b; Grljušić et al., 2008).

The aim of this investigation was to estimate the effects of various $\mathrm{pH}$ levels $(4,5,6$ and 7$)$ on germination and early seedling growth in two red clover genotypes (cv. K-17 and cv. Kolubara).

\section{Materials and Methods}

Effects of four $\mathrm{pH}$ levels of germination media (4, 5, 6 and 7) on germination and early seedling growth of red clover were tested in laboratory conditions of the Institute for Animal Husbandry in Belgrade, in January 2011. Seeds of two red clover genotypes, cv. K-17 and cv. Kolubara, were used as material. Thousand seeds weight were $1.78 \mathrm{~g} \mathrm{(cv.} \mathrm{K-17)} \mathrm{and} 1.93 \mathrm{~g}$ (cv. Kolubara). The seeds were stored in paper bags in laboratory room. Seeds were sterilized in $1 \%$ sodium hypochlorite solution during $5 \mathrm{~min}$ and washed three times by sterilized distilled water. Seeds were mechanically scarified by rubbing them gently with fine quartz sand in a ceramic mortar.

Germination tests were carried out at $20 \pm 1{ }^{\circ} \mathrm{C}$, in sterile plastic germination boxes with lids $(15 \times 21 \times 4 \mathrm{~cm})$ on filter paper soaked with $10 \mathrm{ml}$ of water media various $\mathrm{pH}(4,5,6$ and 7), using four replicates of 100 seeds. Distilled water has a $\mathrm{pH}$ of 7 . Water $\mathrm{pH}$ was adjusted by addition of $0.1 \mathrm{M} \mathrm{HCl}$ to desired $\mathrm{pH}$ (Agić, et al., 2009). Plastic germination boxes were arranged in a Randomized Complete Block Design (RCBD). Germination energy (GE) was evaluated after 4 days. Germination (G), percentage of dead or infected seeds (DIS), percentage of hard seed (HS), normal (NS) and abnormal seedlings (AS), root length (RL), shoot length (ShL), seedling length (SeL), fresh weight (FW) and dry weight (DW) of seedling, and seedling vigor index (SVI) were evaluated after 10 days. Seeds were considers fully germinated when root length measured $2 \mathrm{~mm}$ (ISTA, 1999). NS, AS, RL, ShL, SeL, FW and DW were determined on 25 randomly selected seedlings in each treatment and replication. Seedlings were dried in a hot air an oven at $80^{\circ} \mathrm{C}$ for 24 hours (Perry, 1977) and mean dry weight of seedling (DW) 
was recorded. Vigor index was calculated as per equation by Abdul-Baki and Anderson et al. (1973):

Vigor Index $=($ Root length + Shoot length $) \mathrm{x}$ Germination percentage.

Data were processed by ANOVA. Statistical tests were performed using the Statistical Package for Social Sciences (SPSS) (version 5.0) and Costat. Test of difference significance between treatments were estimated by LSD.

\section{Results and Discussion}

Results of ANOVA indicated that genotype had significant effect on HS $(\mathrm{P}<0.01)$, RL $(\mathrm{P}<0.01)$, ShL $(\mathrm{P}<0.01)$, SeL $(\mathrm{P}<0.01)$, FW $(\mathrm{P}<0.01)$ and SVI $(\mathrm{P}<0.01)$ (Table 1). The $\mathrm{pH}$ of germination media significantly affected the NS $(\mathrm{P}<0.01)$, AS $(\mathrm{P}<0.01)$, RL $(\mathrm{P}<0.05)$, ShL $(\mathrm{P}<0.01)$, SeL $(\mathrm{P}<0.01), \mathrm{FW}(\mathrm{P}<0.01)$ and SVI $(\mathrm{P}<0.05)$. Genotype and $\mathrm{pH}$ did not affect the GE, G, DIS and DW significantly.

$\mathrm{GE}$, in average for $\mathrm{pH}$ and genotypes, was $94.03 \%$. Genotype Kolubara, in average for $\mathrm{pH}$, had higher GE (94.56\%) than genotype K-17 (93.50\%). Seeds of red clover were not as sensitive to low $\mathrm{pH}$. Maximal GE (95.62\%), in average for genotypes, was at $\mathrm{pH} 6$, and minimal GE $(92.00 \%)$ was at $\mathrm{pH} 4$. These values were not significant. Seed was able to germinate at all tested $\mathrm{pH}$ levels of media. The result shows large environmental adaptation ability of red clover, which is in agreement with research of Quesenberry et al. (1991). Bukvić et al. (2009) obtained the lowest average germination energy of red clover at $\mathrm{pH} 6$.

Average $\mathrm{G}$ for $\mathrm{pH}$ and genotypes, was $96.56 \%$. Kolubara had higher $\mathrm{G}$ (97.25\%) than K-17 (95.88\%). In average for genotypes, minimal $\mathrm{G}$ was recorded at $\mathrm{pH} 4(95.25 \%)$. Maximal $\mathrm{G}$ was recorded at $\mathrm{pH} 5$ (97.25\%). These differences were not statistically significant. Agic et al. (2009) reported that $\mathrm{pH}$ of germination media significantly affected red clover germination $(\mathrm{P}<0.05)$. Their results indicated that highest seed $\mathrm{G}$ was found at pH 5. Bukvić et al. (2009) obtained higher $\mathrm{G}$ of red clover at $\mathrm{pH} 4$ and $\mathrm{pH} 5$ than at $\mathrm{pH} 6$ and $\mathrm{pH} 7$.

Normal seedlings are those show the capacity for continued development into normal plant (ISTA, 2009). NS, in average for $\mathrm{pH}$ and genotypes, was $89.28 \%$. In average for $\mathrm{pH}, \mathrm{K}-17$ had higher NS (89.44\%) than Kolubara $(89.12 \%)$. The difference was not statistically significant. $\mathrm{pH}$ has a significant effect on NS. The means in the Table 1 shows that at $\mathrm{pH} 7$ the NS is $93.38 \%$, at $\mathrm{pH} 6$ is $91.25 \%$, at $\mathrm{pH} 5$ is $90.50 \%$ and at $\mathrm{pH} 4$, this amount decreases to $82.00 \%$. These values differed statistically significant. 
Table 1. Effect of different pH levels on germination energy (GE), germination (G), percentage of dead or infected seeds (DIS), percentage of hard seed (HS), normal (NS) and abnormal seedlings (AS), root length (RL), shoot length (ShL), seedling length (SeL), fresh weight (FW) and dry weight (DW) of seedling, and seedling vigor index (SVI)

\begin{tabular}{|c|c|c|c|c|c|c|c|c|c|c|c|c|c|}
\hline \multirow{2}{*}{$\begin{array}{c}\text { Genotype } \\
\text { (A) }\end{array}$} & \multirow[b]{2}{*}{$\begin{array}{l}\mathrm{pH} \\
\text { (B) }\end{array}$} & \multicolumn{12}{|c|}{ Traits } \\
\hline & & $\begin{array}{l}\mathrm{GE} \\
(\%)\end{array}$ & $\begin{array}{c}\mathrm{G} \\
(\%)\end{array}$ & $\begin{array}{l}\text { NS } \\
(\%)\end{array}$ & $\begin{array}{l}\text { AS } \\
(\%)\end{array}$ & $\begin{array}{l}\text { DIS } \\
(\%)\end{array}$ & $\begin{array}{l}\text { HS } \\
(\%)\end{array}$ & $\begin{array}{l}\mathrm{RL} \\
(\mathrm{cm})\end{array}$ & $\begin{array}{l}\mathrm{ShL} \\
(\mathrm{cm})\end{array}$ & $\begin{array}{l}\mathrm{SeL} \\
(\mathrm{cm})\end{array}$ & $\begin{array}{l}\text { FW } \\
(\mathrm{mg})\end{array}$ & $\begin{array}{l}\text { DW } \\
(\mathrm{mg})\end{array}$ & SVI \\
\hline \multirow{5}{*}{$\mathrm{K}-17$} & 4 & 91.50 & 94.50 & 83.50 & 11.00 & 3.0 & 2.5 & 2.40 & 4.88 & 7.28 & 13.70 & 1.42 & 688 \\
\hline & 5 & 92.00 & 96.00 & 90.00 & 6.00 & 3.0 & 1.0 & 2.70 & 5.18 & 7.88 & 19.27 & 1.42 & 756 \\
\hline & 6 & 95.00 & 96.00 & 91.00 & 5.00 & 3.0 & 1.0 & 2.33 & 5.55 & 7.88 & 17.75 & 1.41 & 756 \\
\hline & 7 & 95.50 & 97.00 & 93.2 & 3.75 & 3.0 & 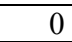 & 2.28 & 5.65 & 7.93 & 18.88 & 1.53 & 769 \\
\hline & $\mathrm{M}$ & 93.50 & 95.88 & 89.44 & 6.44 & 3.0 & .12 & 2.43 & 5.32 & 7.75 & 17.40 & 1.44 & 742 \\
\hline \multirow{5}{*}{ Kolubara } & 4 & 92.50 & 96.00 & 80.50 & 15.50 & 4.0 & 0 & 2.80 & 5.05 & 7.85 & 15.97 & 1.43 & 753 \\
\hline & 5 & 94.00 & 98.50 & 91.00 & 7.50 & 1.5 & 0 & 2.95 & 5.45 & 8.40 & 22.22 & 1.57 & 828 \\
\hline & 6 & 96.25 & 97.50 & 91.50 & 6.00 & 2.0 & 0 & 2.53 & 6.15 & 8.68 & 23.88 & 1.63 & 847 \\
\hline & 7 & 95.50 & 97.00 & 93.50 & 3.50 & 3.5 & 0 & 2.50 & 6.10 & 8.60 & 20.14 & 1.69 & 834 \\
\hline & $\mathrm{M}$ & 94.56 & 97.25 & 89.12 & 8.12 & 2.75 & 0 & 2.70 & 5.69 & 8.38 & 20.55 & 1.58 & 816 \\
\hline & 4 & 92.00 & 95.25 & 82.00 & 13.25 & 3.50 & 1.25 & 2.60 & 5.00 & 7.57 & 14.84 & 1.42 & 720 \\
\hline & 5 & 93.00 & 97.25 & 90.50 & 6.75 & 2.25 & 0.50 & 2.82 & 5.32 & 8.14 & 20.74 & 1.50 & 792 \\
\hline & 6 & 95.62 & 96.75 & 91.25 & 5.50 & 2.50 & 0.50 & 2.43 & 5.85 & 8.28 & 20.82 & 1.52 & 802 \\
\hline & 7 & 95.50 & 97.00 & 93.38 & 3.62 & 3.25 & 0 & 2.39 & 5.88 & 8.27 & 19.51 & 1.61 & 802 \\
\hline & $\mathrm{M}$ & 94.03 & 96.56 & 89.28 & 7.28 & 2.88 & 0.56 & 2.57 & 5.51 & 8.07 & 18.98 & 1.51 & 779 \\
\hline
\end{tabular}

\begin{tabular}{|c|c|c|c|c|c|c|c|c|c|c|c|c|}
\hline \multirow{2}{*}{ LSD } & \multicolumn{3}{|c|}{ GE } & \multicolumn{3}{|c|}{ G } & \multicolumn{3}{|c|}{ NS } & \multicolumn{3}{|c|}{ AS } \\
\hline & A & B & $A * B$ & A & B & $A * B$ & A & B & $A * B$ & A & B & $A * B$ \\
\hline test & ns & $\mathrm{ns}$ & $\mathrm{ns}$ & $\mathrm{ns}$ & ns & ns & $\mathrm{ns}$ & $* *$ & ns & ns & $* *$ & $\mathrm{~ns}$ \\
\hline $5 \%$ & 2.35 & 3.32 & 4.67 & 2.06 & 2.91 & 4.09 & 3.02 & 4.27 & 6.00 & 2.33 & 3.30 & 4.63 \\
\hline $1 \%$ & 3.20 & 4.53 & 6.33 & 2.80 & 3.96 & 5.54 & 4.11 & 5.82 & 8.13 & 3.18 & 4.49 & 6.28 \\
\hline LSD & & DIS & & & HS & & & RL & & & ShL & \\
\hline$F$ test & ns & ns & ns & $* *$ & ns & ns & $* *$ & $* *$ & ns & ** & * & ns \\
\hline $5 \%$ & 1.75 & 2.47 & 3.47 & 0.80 & 1.13 & 1.58 & 0.19 & 0.27 & 0.38 & 0.21 & 0.30 & 0.42 \\
\hline $1 \%$ & 2.38 & 3.37 & 4.70 & 1.08 & 1.53 & 2.14 & 0.27 & 0.37 & 0.52 & 0.28 & 0.41 & 0.57 \\
\hline LSD & & $\mathrm{SeL}$ & & & FW & & & DW & & & SVI & \\
\hline $\mathrm{F}$ test & ** & $* *$ & ns & ** & $* *$ & ns & ns & ns & ns & $* *$ & * & $\mathrm{ns}$ \\
\hline $5 \%$ & 0.32 & 0.45 & 0.62 & 1.68 & 2.37 & 3.33 & 0.16 & 0.22 & 0.31 & 37.12 & 52.50 & 73.69 \\
\hline $1 \%$ & 0.43 & 0.61 & 0.85 & 2.29 & 3.23 & 4.52 & 0.21 & 0.30 & 0.42 & 50.54 & 71.48 & 99.86 \\
\hline
\end{tabular}

** - significant at $1 \%$ level of probability, * - significant at $5 \%$ level of probability and ns - not significant

Abnormal seedlings are those which do not show capacity for continued development into normal plants when grown in good quality soil, under favorable condition of heat, light ad water supply (ISTA, 2009). Average AS for $\mathrm{pH}$ and genotypes was $7.28 \%$. The higher AS was obtained from Kolubara $(8.12 \%)$ than K-17 (6.44\%). The genotype did not affect the AS significantly. AS was decreased by increasing the $\mathrm{pH}$ from $4(13.25 \%)$ to $7(3.62 \%)$. $\mathrm{pH}$ has a significant effect on AS. 
DIS, in average for $\mathrm{pH}$ and genotypes, was $2.88 \%$. Genotype and $\mathrm{pH}$ did not significantly affect on DIS. Kolubara had lower DIS for $0.25 \%$ than K-17 (3.00\%). In average for genotypes, maximal DIS was recorded at $\mathrm{pH} 4(3.50 \%)$, while minimal DIS was recorded at $\mathrm{pH} 5(2.25 \%)$.

The number of HS, which not germinate within 10 days after placement on germinator, is normally $7-15 \%$ in red clover (Chmelař, 1947). Ünal (2004) and Elçi (2005) concluded that the environmental and genetic factors contribute to HS formation in Fabaceae family. HS, in average for $\mathrm{pH}$ and genotypes, was $0.56 \%$. The genotype had significant effect on HS $(\mathrm{P}<0.01)$. Kolubara had lower HS by $1.12 \%$ than $\mathrm{K}-17(1.12 \%)$. The $\mathrm{pH}$ did not affect the HS. The HS ranged from $0 \%$ $(\mathrm{pH} 7)$ to $1.25 \%(\mathrm{pH} 4)$. Results indicate that the hard seed characteristic is under genetic control.

Average RL for $\mathrm{pH}$ and genotypes, was $2.57 \mathrm{~cm}$. Kolubara had higher RL for $0.27 \mathrm{~cm}$ than K-17 $(2.43 \mathrm{~cm})$. The difference was not statistically significant. In average for $\mathrm{pH}$, differences in $\mathrm{RL}$ among tested $\mathrm{pH}$ levels were significant RL. The lowest value was recorded at $\mathrm{pH} 7(2.39 \mathrm{~cm})$. The highest RL value was recorded at pH $5(2.82 \mathrm{~cm})$. This result is in agreement with research of Bukvić et al. (2009). Their results indicated that maximum RL at $\mathrm{pH} 5$ and minimum RL at $\mathrm{pH}$ 7. Agić et al. (2009) found that higher RL at $\mathrm{pH} 5$ and $\mathrm{pH} 6$ than at $\mathrm{pH} 4$ and $\mathrm{pH}$ 7. Their results show that $\mathrm{RL}$ on $9^{\text {th }}$ germination day varied from $9.1 \mathrm{~mm}$ at $\mathrm{pH} 7$ to 11.2 $\mathrm{mm}$ at $\mathrm{pH} 5$ in average.

Average $\mathrm{ShL}$ for $\mathrm{pH}$ and genotypes, was $5.51 \mathrm{~cm}$. Kolubara had higher ShL for $0.37 \mathrm{~cm}$ than K-17 $(5.32 \mathrm{~cm})$. The difference was statistically significant. The highest $\mathrm{ShL}$ was obtained at $\mathrm{pH} 7(5.88 \mathrm{~cm})$ and $\mathrm{pH} 6(5.85 \mathrm{~cm})$. These values were significant differed from the $\mathrm{ShL}$ at $\mathrm{pH} 5(5.32 \mathrm{~cm})$ and $\mathrm{pH} 4(5.00 \mathrm{~cm})$. Bukvić et al. (2009) obtained highest ShL at pH 4, and lowest ShL at pH 7. Bukvić et al. (2008) reported that RL and $\mathrm{ShL}$ of alfalfa significantly depended $(\mathrm{P}<0.01)$ on $\mathrm{pH}$ of water solution. They found the highest average values for both traits at $\mathrm{pH}$ 4.00. Significant effect $\mathrm{pH}$ on $\mathrm{RL}$ and $\mathrm{ShL}$ has been examined in several leguminous crop species: white clover (Bukvic et al., 2007b), soybean (Grljušić et al., 2007) and field pea (Bukvic et al., 2007c).

$\mathrm{SeL}$, in average for $\mathrm{pH}$ and genotypes, was $8.07 \mathrm{~cm}$. Kolubara had higher SeL for $0.63 \mathrm{~cm}$ than K-17 $(7.75 \mathrm{~cm})$. The difference was statistically significant. Significant differences were found for values obtained at different $\mathrm{pH}$ values. The highest $\mathrm{SeL}$ was found at $\mathrm{pH} 7(8.27 \mathrm{~cm})$ and $\mathrm{pH} 6(8.28 \mathrm{~cm})$, and the lowest at $\mathrm{pH}$ $4(7.57 \mathrm{~cm})$. SeL differences, at $\mathrm{pH}$ levels 7,6 and $5(8.14 \mathrm{~cm})$ were not significant. Bukvić et al. (2009) found that highest average $\mathrm{SeL}$ at $\mathrm{pH} 4$, and lowest $\mathrm{SeL}$ at $\mathrm{pH}$ 7.

$\mathrm{FW}$, in average for $\mathrm{pH}$ and genotypes, was $18.98 \mathrm{mg}$. The genotype had significant effect on FW. Kolubara, in average for $\mathrm{pH}$, had higher FW $(20.55 \mathrm{mg})$ than genotype K-17 (17.40 mg). The pH levels had significant effect on the FW. 
Minimal FW (14.84 mg), in average for genotypes, was at $\mathrm{pH} 4$ and maximal FW (20.82 $\mathrm{mg})$ at $\mathrm{pH} 7$.

Average DW for $\mathrm{pH}$ and genotypes, was $1.51 \mathrm{mg}$. Genotype and $\mathrm{pH}$ did not affect on DW significantly. Kolubara had higher DW (1.58 mg) than K-17 (1.44 mg). In average for genotypes, minimal DW was recorded at $\mathrm{pH} 4(1.42 \mathrm{mg})$. Maximal DW was recorded at $\mathrm{pH} 7(1.61 \mathrm{mg})$.

The vigor comprises a set of characteristics that determine seed vigor and is influenced by environmental conditions and handling during the stages of preand post-harvest (Vieira and Carvalho, 1994). In addition to the above, determines the longevity of seed vigor, without adverse consequences (ISTA, 2009). SVI, in average for $\mathrm{pH}$ and genotypes, was 779 . The genotype had significant effect on SVI. Kolubara had higher SVI (816) than K-17 (742). In average for genotypes, pH had significantly different effects on the SVI. The minimum SVI was found at $\mathrm{pH}$ 4 (720). The SVI was higher at $\mathrm{pH} 5$ (792), $\mathrm{pH} 6$ (802) and $\mathrm{pH} 7$ (802) than at $\mathrm{pH}$ 4.

The interactions between varieties and $\mathrm{pH}$ levels were not significant for all studied traits.

\section{Conclusion}

The RL, ShL, SeL, FW and SVI of red clover were significantly affected by genotype and $\mathrm{pH}$. Also, the $\mathrm{pH}$ levels had significant effect on the NS and AS, and the genotype had significant effect on HS. Red clover seed it is not sensitive to $\mathrm{pH}$ stress. The results of this experiment have showed the importance of $\mathrm{pH}$ on early seedling growth. Genotype and pH did not affect on GE, G, DIS and DW significantly. The lowest GE, G, NS, ShL, SeL, FW and SVI were found at $\mathrm{pH} 4$. The highest DIS, HS and AS were found at $\mathrm{pH} 4$. Results indicate on ability growth of seedling of red clover of different $\mathrm{pH}$ levels, especially in acidic environment. Also, results indicate that testing of genotypes of red clover in the early seedling growth at different $\mathrm{pH}$ levels, would be helpful in the identification and selection of genotypes for particular location (soil).

\section{Acknowledgment}

The research was supported by the Ministry of Education and Science of Republic of Serbia, project TR 31053. 


\title{
Uticaj stresa usled promene pH na klijanje i porast klijanaca crvene deteline
}

\author{
V. Mandić, Z. Tomić, V. Krnjaja, Z. Bijelić, M. Žujović, A. Simić, S. Prodanović
}

\section{Rezime}

Cilj istraživanja bio je da se odredi uticaj različitih nivoa $\mathrm{pH}$ vrednosti (4, 5, 6 i 7) na energiju klijanja (EK), klijavost (K), neklijala i bolesna semena (NB), tvrda semena (TS), normalne klijance (NK), abnormalne klijance (AK), dužinu korena (DK), dužinu hipokotila (DH), ukupnu dužinu klijanca (UDK), svežu masu klijanaca (SvMK), suvu masu klijanaca (SuMK) i vigor indeks klijanaca (VIK) kod dva genotipa crvene deteline (cv. K-17 i cv. Kolubara). Ogledi su izvedeni u laboratorijskim uslovima u Institutu za stočarstvo u Beogradu, u januaru 2011. godine.

$\mathrm{pH}$ vrednost imala je značajan uticaj na NK $(\mathrm{P}<0.01), \mathrm{NB}(\mathrm{P}<0.01)$, DK $(\mathrm{P}<0.05)$, DH $(\mathrm{P}<0.01)$, UDK $(\mathrm{P}<0.01)$, SvMK $(\mathrm{P}<0.01)$ i VIK $(\mathrm{P}<0.05)$. Najmanje vrednosti za EK, K, NK, DH, UDK, SvMK i VIK zabeležene su na pH 4. Takođe, najveća učestalost NB, TS i AK registrovana je na $\mathrm{pH} 4$. Genotipovi su se značajno razlikovali za sledeće osobine: TS $(\mathrm{P}<0.01)$, DK $(\mathrm{P}<0.01)$, DH $(\mathrm{P}<0.01)$, UDK $(\mathrm{P}<0.01)$, SvMK $(\mathrm{P}<0.01)$ i VIK $(\mathrm{P}<0.01)$. Utvrđeno je da genotipovi i $\mathrm{pH}$ nemaju značajan uticaj na EK, K, NB i SuMK.

\section{References}

ABDUL-BAKI A.A., ANDERSON J.D. (1973): Relationship between decarboxilation of glutamic acid and vigour in soybean seed. Crop Science, 13, 222-226.

AGIĆ D., BUKVIĆ G., GRLJUŠIĆ S., BEŠLO D., HORVATIĆ J., NOVOSELOVIĆ D. (2009): Effect of $\mathrm{pH}$ on $\alpha$-amylase activity and early seedling growth of red clover (Trifolium pratense L.). Notulae Botanicae Horti Agrobotanici Cluj-Napoca, 37, 2, 77-80.

BUKVIĆ G., GRLJUŠIĆ S., JOSIPOVIĆ A., GREGER Ž., MARIJANOVIĆ M., BILUŠIĆ LJ. (2009): Klijanje sjemena crvene deteline (cv Viola) u zavisnosti o pH vrijednosti vodene otopine i starosti sjemena. Poljoprivreda, 15, 1, 1-7.

BUKVIC G., GRLJUSIC S., LISKA A., GANTNER R., JAGIC M., KARAKAS M. (2007b): Germination of white clover genotypes. Book of Abstracts of $42^{\text {nd }}$ Croatian $\& 2^{\text {nd }}$ International Symposium on Agriculture, Opatija, Croatia, February 13-16, 87-88. 
BUKVIĆ G., GRLJUŠIĆ S., ROZMAN V., LIŠKA A., LOVIĆ I. (2008): Utjecaj pH i temperature na energiju klijanja, klijavost, dužinu korijena i hipokotila klijanaca različitih kultivara lucerne (Medicago sativa L.). Poljoprivreda, 14, 1, 9-14. BUKVIC G., GRLJUSIC S., ROZMAN V., LUKIC D., LACKOVIC R., NOVOSELOVIC D. (2007c): Seed age and $\mathrm{pH}$ of water solution effects on field pea (Pisum sativum L.) germination. Notulae Botanicae Horti Agrobotanici ClujNapoca, 35, 1, 20-26.

BUKVIC G., GRLJUSIC S., ROZMAN V., POPOVIC S., LUCIN V. (2007a): Influence of temperature and $\mathrm{pH}$ value on germination of alfalfa genotypes. Book of abstracts of $42^{\text {nd }}$ Croatian $\& 2^{\text {nd }}$ International Symposium on Agriculture, Opatija, Croatia, February 13-16, 85-86.

CHMELA ̌ F. (1947): Germination of imbibition resistant (hard) seeds of red clover (Trifolium pratense) placed into germinator before 26 years. Journal of Forest Science, 19, 222-233.

DICKSON M.H., BOETTGER M.A. (1984): Emergence, growth, and blossoming of bean (Phaseolus vulgaris) at suboptimal temperatures. Journal of the American Society for Horticultural Science, 109, 257-260.

DUKE J.A. (1981): Handbook of legumes of world economic importance. New York, Plenum Press, 173-77.

ELÇI S. (2005): Legume and graminae feed plants. Turkish Ministry of Agriculture and Rural Affairs, Ankara, Turkey, 84-85.

GRLJUŠIĆ S., BUKVIĆ G., RAPČAN I., AGIĆ D., HORVATIĆ J. (2008.): The effects of soil and temperature on early white clover growth. Cereal Research Communications, 36, 1, 643-646.

GRLJUŠIĆ S., BUKVIĆ G., VRATARIĆ M., ANTUNOVIĆ M., SUDARIĆ S., PREPELAC I. (2007): Utjecaj pH vodene otopine na klijavost sjemena soje. Poljoprivreda, 13, 2, 1-6.

ISTA (1999): International rules for seed testing. International Seed Testing Association (ISTA), Seed Science and Technology, 27, Supplement.

ISTA (2009): International rules for seed testing. International Seed Testing Association (ISTA), Switzerland.

KATIĆ S., VASILJEVIĆ S., MILIĆ D., LAZAREVIĆ B., DUGALIĆ G. (2006): Mogućnost gajenja lucerke i crvene deteline na pseudogleju uz primenu krečnjaka i rizobiuma. Zbornik radova Naučnog instituta za ratarstvo i povrtarstvo, 42, 31-40.

KLOS K.L.E. (1999): Variation in alfalfa (Medicago sativa L.) for germination and seedling vigor at suboptimal temperatures; and laboratory and field responses to selection within six alfalfa populations. Ph. D. dissertation, Iowa State University, Ames, (Diss. Abstract, ISU 1999, K58).

QUESENBERRY K.H., SMITH R.R., TAYLOR N.L., BALTENSPERGER D.D., PARROTT W.A. (1991): Genetic nomenclature in clovers and special-purpose legumes: I. Red clover and white clover. Crop Science, 31, 4, 861-867. 
PERRY D.A. (1977): A vigour test for seeds of barley (Hordeum vulgare) based on measurement of plumule growth. Seed Science and Technology, 5, 709-719.

SAMINY C., TAILOR A.G., KENNY T.J. (1987): Relationship of germination and vigor tests to field emergence of snap beans (Phaseolus vulgaris L.). Journal of Seed Technology, 11, 23-34.

SATTELL R., DICK R., HEMPHILL D., MCGRATH D. (1998): Oregon cover crops: Red clover (Trifolium pratense). http://extension.oregonstate.edu/catalog/html/em/em8701/

SZYRMER J., SZCZEPANSKA K. (1981): Screening of soybean genotypes for cold-tolerance during germination. Z. Pflanzenzucht, 88, 255-260.

TANAKA A., HITSUDA K., TSUCHIHASHI Y. (1984): Tolerance to low pH and low available phosphorus of various field and forage crops. Soil Science and Plant Nutrition, 30, 39-49.

TAYLOR N.L., SMITH R.R. (1995). Red clover. In: BARNES R.F., MILLER D., NELSON C.J. (eds), An introduction to grassland agriculture. Iowa State University Press, Ames, IA, Forages, 1, 217-226.

TOMIĆ Z., LUGIĆ Z., RADOVIĆ J., SOKOLOVIĆ D., NEŠIĆ Z., KRNJAJA V. (2007): Perennial legumes and grasses stable source of quality livestock fodder Feed. Biotechnology in Animal Husbandry, 23, 5-6, 559-572.

VIEIRA R.D., CARVALHO N.M. (1994): Teste de vigor em sementes. Funep/Unesp, Jaboticabal, Brasil.

YOKOTA S., OJIMA K. (1995): Physiological response of root tip of alfalfa to low $\mathrm{pH}$ and aluminium stress in water culture. Plant Soil, 171, 1, 163-165.

ÜNAL M. (2004): Bitki (Angiosperm) Embriyolojisi, Marmara University, Istanbul, Turkey, 282-285.

Received 30 June 2011; accepted for publication 15 August 2011 